*M. Sukhanov, K. Markov, (VNIIgeosystem), K. Koronkevich, (VIRG-Rudgeophysica)

\title{
SUMMARY
}

Recently, a number of geological information resource have been developed by various organisations, based on different internet technologies. The need arises to integrate these into a unified information system with minimal interference into the source code and functioning of the existing applications. A specialised software framework has been developed for enhancing web pages with hyperlinks pointing to corresponding objects of other web sites or their spatial representation in GIS component. The relations between objects of different information sources are provided by harvested metadata stored in DBMS of multi-functional geo-information server MGS. The technology was implemented for Russian geological information system SOBR Rosnedra.

\section{Інтеграція різнорідних геологічних інформаційних ресурсів та їі реалізація в системі забезпечення робіт "СОБР Роснедра"}

*М.Г. Суханов, К.М. Марков, (Всеросійський науково-дослідний інститут геологічних, геофізичних $i$ геохімічних систем (ВНИИгеосистем)), к.о. Коронкевич, ("ВИРГРудгеофизика")

\section{РЕЗЮМЕ}

Останнім часом з'явилася велика кількість геологічних інформаційних систем і ресурсів, створених з використанням різнорідних програмних засобів і інтернет-технологій. Існує нагальна необхідність інтеграції їх в єдину систему, звівши до мінімуму зміни в їх вихідних коду і способам функціонування. Була розроблене спеціальне програмне середовище, що дозволяє розширювати функціональність існуючих веб-форм і сторінок шляхом впровадження гіперпосилань на відповідні об'єкти інших веб-ресурсів, або на їх просторове уявлення в ГІСкомпоненті. Зв'язки між об'єктами з різних інформаційних ресурсів вибудовуються на основі метаданих, зібраних в метабази, що є підсистемою багатофункціонального геоінформаційного сервера БГС. Дана технологія була реалізована і випробувана при створенні веб-порталу системи забезпечення робіт "СОБР Роснедра". 


\section{Интеграция разнородных геологических информационных} ресурсов и её реализация в системе обеспечения работ СОБР

\section{Роснедра}

*М.Г. Суханов, К.Н. Марков, (ВНИИгеосистем), К.А. Коронкевич, (ВИРГ-Рудгеофизика)

\section{РЕЗЮМЕ}

В последнее время появилось большое число геологических информационных систем и ресурсов, созданных с использованием разнородных программных средств и интернеттехнологий. Существует насущная необходимость интеграции их в единую систему, сведя к минимуму изменения в их исходных кода и способам функционирования. Была разработана специальная программная среда, позволяющая расширять функциональность существующих веб-форм и страниц путём внедрения гиперссылок на соответствующие объекты других вебресурсов, либо на их пространственное представление в ГИС-компоненте. Связи между объектами из различных информационных ресурсов выстраиваются на основе метаданных, собранных в метабазе, являющейся подсистемой многофункционального геоинформационного сервера МГС. Данная технология была реализована и опробована при создании веб-портала системы обеспечения работ СОБР Роснедра. 